\title{
CONSEQUENCES OF THE DECISION OF THE CONSTITUTIONAL COURT OF ROMANIA NO. 2/2017 ON THE EXTRAORDINARY APPEAL PATH OF THE REVIEW
}

\section{M.PĂTRĂUŞ, D.-D. PĂTRĂUŞ}

\author{
Mihaela PĂTRĂUȘ \\ Department of Public Law \\ Faculty of Law \\ University of Oradea, Romania \\ *Correspondence: Mihaela Pătrăuş, Oradea, 26 General Magheru, Oradea, Romania \\ E-mail: mihaelapatraus@yahoo.com

\section{Darius-Dennis PĂTRĂUȘ} \\ Faculty of Law \\ "Babeș-Bolyai" University of Cluj-Napoca, Romania \\ E-mail: denispatraus@yahoo.com
}

\begin{abstract}
The central element of this extraordinary appeal is the judicial error. The review involves finding a legal error in the criminal case settled by a final judgment, which was based on an erroneous assessment of the state of affairs. Exercising appeals does not create a new procedural report, but only extends the initial report in this new procedural phase. In our judicial system, the unanimous classification is that appeals are divided into two categories: ordinary ways and extraordinary ways. Thus, before the decision, the case under Article 453 (1) (a) could be invoked as a ground for review only in favor of the convicted person or of the one to whom the waiver of the punishment or deferment of the punishment or termination of the criminal proceedings, if the review is aimed at obtaining an acquittal. Therefore, this case of revision could not be used to the detriment of the person who was acquitted or who was ordered to terminate the criminal proceedings, with the aim of reaching a decision on conviction, renunciation of the punishment or postponement of the application punishment.
\end{abstract}

KEYWORDS: decision CCR 2/2017, extraordinary appeal, review, role of the prosecutor, acquittal.

\section{INTRODUCTION}

In the course of criminal justice, some legal errors are possible that can spring for countless reasons. Thus, legal errors are possible due to the fact that the court does not know the true factual situation; the use of distorted evidence (due to criminal activities); corruption of organs that have solved the cause; the existence of contradictory decisions ${ }^{1}$.

The essence of any remedy in criminal matters is that no judicial decision based on the misconduct or misinterpretation of the legal norms or the erroneous preconceived factual circumstances generated by a multitude of circumstances, some attributable to the judicial bodies, others not imputable to them, do not come to produce the effects that a final judgment in criminal matters may develop ${ }^{2}$. Therefore, in order to overcome any mistakes made at the

\footnotetext{
${ }^{1}$ According to I. Neagu, Criminal Procedure Treaty, Ed. Pro, 1997, p.620.

2 According to M. V. Tudoran, The necessity of introducing in the Criminal Procedure Code a new case of revision of final criminal law rulings on Community law.in Law no. 10/2009, p. 180.
} 
first trial, it is necessary that the adjudication of a case in the main is followed by a subsequent trial, respectively, to take advantage of an extraordinary way of attack.

The extraordinary ways of attack in criminal matters are based on two principles whose importance was highlighted in the case of Hornsby v. Greece ${ }^{3}$, in which the European Court held that "one of the fundamental aspects of the rule of law is the principle of legal certainty requiring, inter alia", that when the courts have pronounced a final solution, their solution can no longer be called into question.Legal security involves the principle of res judicata (the principle of the final character of judgments), and a derogation from that principle can only be justified when exceptional circumstances require it. The principle implies that no party may request the modification of a final and binding court judgment only in order to obtain a new re-examination of the case. The right of access to a court would be illusory if the national judicial systems would allow a binding judgment to remain ineffective at the expense of a party.

The appeal to the reviewisessentially a recourseappeal, sinceafter the invocation of new issues unknown to the court at the time of the case, all the judgeswho have tried the case at first instance are calledupon to analyze the new issues raised and to appreciate if taking in view of thosefound, would have a completelydifferent solution.

The central element of thisextraordinaryway of attackis the judicialerror. The reviewinvolvesfinding a legalerror in the criminal case settled by a final judgment, whichwasbased on an erroneousassessment of the state of affairs.

\section{REVIEW HISTORY}

Although it can still be found in Roman law, under the name restitutio in integrum ${ }^{4}$, the review has acquired the character of an extraordinary way of attack only in modern law. The revision was also known by the old Romanian laws, being regulated in the rule of Ion Sturza in 1826, where it is stated that "the one who has been convicted has the liberty of the pavilion to ask for extravagant research when he has enough evidence to his indignation";in the Organic Regulation of Muntenia in 1832, where revision could be required for the contradiction of judgments and the life of the alleged victim; and Criminal Code BarbuŞtirbei in 1850, where the review was allowed in three cases: contradictory judgments, the existence of the alleged victim and the false testimony ${ }^{5}$

In the old French law, the review was made by Lettres de Revision, which aimed at removing the possibility that a person would remain condemned for an act which later proved to be committed by somebody else. This is the first case of revision existing in all legislation, which concerned the situation of a convicted person who was guilty of the evidence administered during the trial, but who subsequently proved to be innocent because of circumstances or deeds discovered after the conviction. For this reason, the first extraordinary appeal was the review, with the sole purpose of reviewing the sentenced person ${ }^{6}$.

Under English law, the reviewhad a difficultpathbecauseitwas not evenadmitted in criminalmatters. Anyunjustbriberyoffered by jurorscouldbecanceled by the President of the Court, whocouldrefer the case back to court ${ }^{7}$.

The European Court of Human Rights, in its case-law, ruled on the nature of extraordinary ways of attack. In Mitrea v. Romania ${ }^{8}$, the Court assessed the extraordinary remedies that an

\footnotetext{
${ }^{3}$ Case Hronsby v. Greece, Case 18357/91 of 19 March 1997, source: http://jurisprudentacedo.com/HORNSBYc.-GRECIA-articolul-6-paragraful-1-din-Convention-incalcare.html, accessed at 02.11.2017, hour 09:16.

${ }^{4}$ According to T. Tanoviceanu, Treaty of Law and Criminal Procedure, vol. V, Bucharest, 1927, Printing, "CurierulJudiciar", p.596 in I. Neagu, op.cit, p.620.

${ }^{5}$ I. Neagu,op.cit, p.621.

${ }^{6}$ According to P. Bouzat, J. Pinatel. Traite de droit penal et de criminologie. Tome II, LibrairieDalloz, Paris, 1963, p. 1167.

${ }^{7}$ According to E. Decusară, Problems of Criminal Procedure. Review in Criminal Procedure, Ed. The Judicial Courier, Bucharest, 1922, p.8.
} 
extraordinary appeal, either brought by one of the parties to the proceedings, can not be upheld on the sole ground that the court whose judgment is being challenged misapplied evidence or misapplied the law in the absence of a fundamental defect that may lead to arbitrariness.

\section{ASPECTS OF COMPARATIVE LAW}

The review body is not identically regulated in all countries, the main differences arising from the regulations of the different systems regarding the application and regulation of the review. We will proceed to an analysis of how the provisions of Art. 453 paragraph 1 letter $\mathrm{C}$ of the Romanian Criminal Procedure Code, as reflected in the laws of other states.

Albania has regulated the revision at Chapter IV, Articles $449-461^{9}$ of the Code of Criminal Procedure, in art. 4, the cases of revision are presented: a) when the facts and grounds on which the sentence was based are not in line with those of another sentence, b) when the sentence is based on a decision of the civil court, which was later revoked; c) when new evidence has emerged or has been discovered after the sentence has been pronounced, which, together with those already administered, proves that the convict is innocent; d) when it is proved that the conviction was given as a result of falsification of the evidence or other fact provided by the law as a crime.

It is noted that in Article 450 letter $\mathrm{c}$ of the Code of Albanian Criminal Procedure, we find a correspondent of art.453 paragraph 1 letter a of the Romanian Criminal Procedure Code and also in their criminal procedural system, new evidence, may be invoked only in support of the convicted person, leading to the acquittal of the defendant. With regard to the persons who may request the review, art. 451letter b, in general terms, that the request for review may also be made by the prosecutor.

Croatia has regulated the review in art. $515-519^{10}$ of the Code of Criminal Procedure. Article 517, includes revision cases:a) for violation of the Criminal Code to the detriment of the convicted person referred to in Article 469, points 1-4 of this law, or for the violation of paragraph 5 of this article, if the court has exceeded its statutory power in a decision on the punishment, the security measure or seizure of the pecuniary benefit; (4) for violation of the criminal procedural provisions referred to in Article 468 (1), (5) and (9) of this Law or for taking part in the decision to grant a decision on the offense. second or third instance of the judge or the secular judge who should have been disqualified (Article 32, paragraph 1) or if the defendant, contrary to his request, denied the right to use his language in the trial or trial before the court judgment; c) breach of the defendant's rights of defense or infringement of procedural provisions in the appeal procedure, if such violation could have influenced the judgment.

The cases under letters $\mathrm{b}$ and $\mathrm{c}$ can only be invoked if they have been the subject of an appeal against the judgment given in the first instance or if they were formulated in the pre-litigation procedure.

From the above, we conclude that, as far as the extraordinary appeal of revision is concerned, in Croatian law, we do not meet a correspondent of art. 453 para. 1 letter a of the Romanian Code of Criminal Procedure.

\footnotetext{
${ }^{8}$ The case of Mitrea v. Romania, no. 26105/03, July 29, 2008, source: http://jurisprudentacedo.com/Mitrea-cRomania-Reinadrare-pe-acelasi-post-dupa-concediere-Despagubiri-Recurs-in-anulare.html, accessed at 04.11.2017, hour 13:44.

${ }^{9}$ http://www.legislationline.org/download/action/download/id/6467/file/Albania_CPC_1995_am2014_en.pdfacce sed at 02.11.2017, hour 13:12.

${ }^{10}$ http://www.legislationline.org/download/action/download/id/4284/file/Croatia_Criminal_proc_code_am2009 en.pdfaccesed at 02.11.2017, hour 16:17.
} 
Regarding the role of prosecutor, art.509 provides that the Attorney General may apply for a review if there has been a violation of criminal law, the Constitution, fundamental rights and freedoms or other domestic or international rights. As a consequence, in the Croatian procedural law, the role of the prosecutor is essential in ensuring the lawfulness of the criminal process.

Germany regulated the revision in Title IV, art. 359-363 ${ }^{11}$, under the heading of "reopening of proceedings through a final judgment", being admissible both in favor of and against the convicted person, including where there are factual elements or new evidence which, independently or in conjunction with other evidence previously administered, support payment of the sentenced person or the application of a lighter punishment or a fundamentally different decision on the application of a re-education or security measure;

Thus, Article 359 of the German Code of Criminal Procedure refers to the invocation of the review only for the reason that new facts or evidence have emerged that could lead to the acquittal of the convict and not to the detriment of him.

However, the German Code of Criminal Procedure also permits the possibility of introducing a petition for review over the sentenced person, in the cases provided by art. 326: A document used to the benefit of the convicted person was false or forged; a witness or expert who has declared against the convicted person was guilty of an intentional or culpable violation of the oath obligation or deliberately made a false statement without being under oath; a judge or an assistant magistrate who participated in the judgment was guilty of a criminal offense in relation to the criminal case.

France has regulated the review institution in Title II, art. 622-626 ${ }^{12}$.Thus, from the analysis of this rule, we deduce the fact that only the review in favor of the convicted person who has committed a felony or misdemeanor can be accepted and can be requested in several cases, including when after the conviction, new factual elements were known at the time of the conviction and are capable of establishing the innocence of the convicted person.

According to art. 623, in the case of new facts and circumstances which were not known at the time of the conviction, can be invoked only in favor of the convict, leading to his acquittal, therefore, neither in the French criminal procedural system, the prosecutor cannot invoke this case of review to the detriment of the convict.

Switzerland regulated the revision in Chapter IV, Articles 410-415 ${ }^{13}$.Article 410 provides the revision cases and admissibility conditions. Among these, we also find the case where new circumstances have emerged that were not known before the decision was taken or evidence came to light that could lead to an acquittal at a considerably reduced penalty or a more severe punishment for the person convicted or convicted of an acquittal.

In light of the above, we understand that Article 453 (1) (a) of the Romanian Code of Criminal Procedure has a correspondent in Art. 410 alin.1 lit. a of the Swiss Code of Criminal Procedure. However, the case of revision is characterized by complexity, and it has indicated in concrete terms the ways that can lead to the revision of a final decision, a matter that has no correspondent in the national regulation.

Paragraph 3 of Article 410 provides that a case may be requested for the benefit of the convicted person and after the case has become forbidden, an aspect that we also encounter in our national law in the form of "final court decisions" and art. 411 of the Swiss Code of Criminal Procedure provides the form and the time limit within which the request for review is to be filed.

As a consequence, we notice differences as to the court where the review request is to be filed, our national law being the first instance; as well as the term, which is clearly and

\footnotetext{
${ }^{11} \mathrm{http} / / /$ legislationline.org/countries/country/28, accesed at 02.11.2017, hour 19:44 .

${ }^{12} \mathrm{http} / / /$ legislationline.org/documents/section/criminal-codes/country/30, accesed at 02.11.2017, hour 21:02.

${ }^{13}$ http://www.legislationline.org/download/action/download/id/6449/file/Swiss_CPC 2007_am2016_en.pdf accessed at 03.11.2017, hour 12:30.
} 
predictably regulated, for a simple reason, the review in Swiss procedural law does not distinguish between a review in favor of or at the expense of the defendant as to the term.

Concerning the role of the prosecutor in Swiss law, by correlating the admissibility conditions and the case under art.410 para.1 letter a, it appears that the prosecutor may request a review only in cases where new circumstances that were not known at the time of the final settlement of the case and the prosecutor requests, through the revision, a more severe punishment for the convicted person or the conviction of a person which had been initially acquitted.

In conclusion, we consider that CCR Decision no.2/2017, although having a correspondent in the Swiss procedural law, should also take into account other institutions of the Swiss system, which operate at a different legal level than the Romanian one. Under Swiss law with regards to case in point a, it is said that the revision comes to support the correct settlement of the causes and the finding of the truth and not to protect the equality of rights between the citizens and the free access to justice, as motivated by the Constitutional Court of Romania. At the same time, we can observe elements of similarity between the CCR Decision and the German, French, Albanian law, which seems to bring Romania closer to the Romanian Criminal Procedure Code from 1968.

\section{CONSEQUENCES OF THE DECISION OF THE CONSTITUTIONAL COURTOF ROMANIA NO. 2/2017 IN THE CONTEXT OF THE REVIEW}

The decision of the Constitutional Court 2/2017, deals with art.453 para. 1 letter a and art.453 par.4 of the first sentence, which stipulate: (1) The review of the final judgments on the criminal side may be requested when: a) there were discovered facts or circumstances that were not known to solve the case and which prove the lack of judgment of the ruling in question; (4) The case referred to in paragraph (1) letter a), is a reason for review if, on the basis of new facts or circumstances, it can be proven that the decision to condemn, waive the punishment, postpone punishment or stop the criminal proceedings may be inappropriate;

The doctrine stated that the provisions of art. 453 para. 1 letter a) are new in relation to the previous regulation, which allowed the review procedure to be exercised also to the detriment of the person who was acquitted or who was ordered to terminate the criminal trial, provided that it has been exercised within one year from the date on which the new facts or circumstances on which the request for revision is based are known (art. 398 para. 2 letter a of the Proc. from 1968] $]^{14}$.

Prior to the decision, the case under Article 453 (1) (a) could be invoked as a ground for review only in favor of the convicted person or of the person to whom the waiver of the punishment or the postponement of the punishment or termination of the criminal proceedings was ordered, if the review process was initiated in order to obtain an acquittal.

In the interpretation and application of the provisions regulating this case of review, it has been pointed out in the judicial practice that the reopening of the criminal prosecution, ordered by the prosecutor by an ordinance against a person other than the convicted person, for the facts which were the subject of the criminal action directed against him, does not constitute a reason for revision, not having the meaning of a new fact or circumstance within the meaning of art.394 paragraph 1 letter a Criminal Procedure Code of 1968.If, however, after the reopening of the criminal prosecution, another person has been sued and convicted for the offense committed solely by the latter against the convicted person, there is the case

\footnotetext{
${ }^{14}$ According to M. Udroiu, A. Andone-Bontaş, G. Bodoroncea, M. Bulancea, V. Constantinescu, D. Grădinaru, C. Jderu, I. Kuglay, C. Meceanu, L. Postelnicu, I. Tocan, AR Trandafir, Code of criminal proceedings. Comment on articles., Ed. C.H. Beck, Bucharest, 2015, p.1125
} 
for revision provided for in Article 394 paragraph 1 letter a C.pr.pen of 1968, and this constitutes a ground for revision according to article 394 paragraph 2 of the same code ${ }^{15}$.

If by the new facts or circumstances the tendency is not to prove the groundlessness of the conviction, to renounce the punishment, to delay the punishment or to stop the criminal proceedings, but only to prove the elements that imply the maintenance of these solutions, the new facts or circumstances is not a reason for review ${ }^{16}$. Thus, in practice, the courts have decided that if the review request, based on new facts or circumstances, sought to change the legal classification, while maintaining the conviction, they are not a case of revision ${ }^{17}$. In other respects, if the new facts or circumstances that tend not to prove the inherent nature of the decision, but the establishment of situations to mitigate criminal responsibility, it does not constitute a reason for revision. At the same time, even if a new act attesting to the existence of a ground for more favorable individualization of the punishment can not constitute a basis for the admission of the petition for revision, and it is not capable of proving the mercilessness of the conviction ${ }^{18}$.

In the grounds of Decision 2/2017, the Constitutional Court revealed that the provisions of Art. 453 par. (3) of the Code of Criminal Procedure regarding the case of review provided for in para. (1) lit. a), as well as the legislative solution contained in the provisions of art. 453 par. (4) the first sentence of the same code, which excludes the possibility of reviewing the payment order for the case provided for in paragraph (1) lit. a) violate the constitutional provisions of art. 16 on equal rights, art. 21 on Free Access to Justice and Art. 131 regarding the role of the Public Ministry, as the civil party is missing the possibility of defending its legitimate rights and interests, and also leaving the prosecutor of the levers necessary for the fulfillment of his specific role in the criminal trial. The Court notes that, if facts or circumstances unrecognizable in the outcome of the case and which prove the mercilessness of the acquittal decision are to be ensured, both the civil party and the prosecutor must be able to request and obtain the restoration of judicial truth by withdrawing the judgment.

Regarding the role of the prosecutor, the decision of the Constitutional Court no. 2/2017, comes to give him a new case in which he can request the review, when facts or circumstances that were not known to the case have been discovered and prove the mercilessness of the order of acquittal in question; basically basing themselves on the regulation of the Criminal Procedure Code from 1968.

We agree with the view expressed in the doctrine that decision no. 2 / 2017, does not confer the prosecutor the power to require review on the civil side, power which he held under the previous rules ${ }^{19}$.

\section{CONCLUSIONS}

In the present paper we have analyzedthe consequences of the decision no.2/2017 of the Constitutional Court of Romania, emphasizing on the role of the prosecutor.

The judicial practice has shown that there are often situations where there is a conflict between two fundamental principles of any system of law.

Legislation to be genuinely effective must allow for review to address legal errors that have a

\footnotetext{
15 H.C.C.J., criminal section, dec.no. 3055 of 12 May 2006; https://legeaz.net/spete-penal-iccj-2006/decizia3055-2006 accessed on 04.11.2017, time: 11:35.

${ }^{16}$ S.C., criminal section, dec.nr.853 of 14 February 2002,https://legeaz.net/spete-drept-penal-csj-2003/decizia853-2002accese on 04.11.2017, time 12:16.

${ }^{17}$ H.C.C.J., criminal section, dec.nr.1869 of 17 March 2005; https://legeaz.net/spete-penal-iccj-2005/decizia1869-2005accese on 04.11.2017, time 13:11.

${ }^{18}$ S.C., criminal section, dec.nr.2101 of 26 September 1997; https://legeaz.net/spete-drept-penal-csj-1997/decizia2101-1997accese on 04.11.2017, time 13:58.

${ }^{19}$ P. Buneci, Gh. Serban, I. Ciolca, I. Dragnea, A. Vasilache, S. Cretu, I. Vasilache, V. Stoica, D. Titian, M. Jiganie-Şerban, New Criminal Procedure Code. Notes. Correlations. Explanations, Ed. C.H.Beck, Bucharest, 2014 , p.540.
} 
negative impact on the legal awareness of citizens. Therefore, the reasons for the review require rigorous and clear regulation to fit the above mentioned coordinates.

Of course, the number of situations thatcan lead to a legal errors not unlimited. Startingfromthis point, the regulations of the different states are designedalmostidentically, withlittle nuances or differences of formulations.

We have shown that even in Roman law there were contingent remedies for the removal of errors, evolving in time with the needs of society and outlining in the form of genuine remedies, but keeping the same reasoning: although it is a form of manifestation of the state authority, repressive justice is not always precise and infallible, which explains the necessity of means of withdrawal of unjust judgments. This explains why the reasons justifying the review of a final criminal judgment were completed with the emergence of new cases that required the annulment of criminal judgments for serious misconduct.

As a result of the admissibility of the objection of unconstitutionality, we observe the optic change of the constitutional litigation court, which on this occasion comes to the solution provided by the old regulation regarding the transformation of the first case of review regarding the occurrence of new facts or circumstances from a case to be invoked solely in favor of the convicted person in a case that can be promoted and defaulted, thus allowing a request for review to be made against an acquittal.

In the light of the new regulation, we have highlighted the limitation of the role of the prosecutor in this procedure, a legislative solution that had the character of evidence, for observing some important principles of the criminal trial. However, inexplicably, the legislator chose to retain the delegation of the prosecutor by the court in charge of resolving the petition for review in order to carry out investigations that can not be directly addressed to the court or would cause delays in re-examining the case. We have shown the ambiguity and shortcomings of this regulation, as well as the fact that it would contravene constitutional provisions.

The assessment of these issues made it possible to establish the superiority of the regulations in the new Criminal Procedure Code, in some cases, but also to reveal the vulnerabilities of the new rules, which we observe would require the intervention of the legislator and not the constitutional court, also European institutions regarding the conduct of a fair trial, with full assurance of the function of the fundamental principles and rules applicable in the court proceedings, suggest this.

In the light of all the issues addressed in this paper, we appreciate that the current system of extraordinary ways of attack is far too restrictive in relation to their purpose. This legal system does not sufficiently guarantee the purpose for which these extraordinary remedies were established, starting from the fact that, for example, the reasons for the review does not cover all situations where there is a high probability of occurrence of factual or legal errors.

\section{BIBLIOGRAPHY}

\section{A) Treaties, courses, monographs:}

1. Neagu, Criminal Procedure Treaty, Ed. Pro, 1997.

2. T. Tanoviceanu, Treaty of Law and Criminal Procedure, vol. V, Bucharest, 1927, Printing, "CurierulJudiciar".

3. E. Decusară, Problems of Criminal Procedure. Review in Criminal Procedure, Ed. The Judicial Courier, Bucharest, 1992.

4. M. Udroiu, A. Andone-Bontaş, G. Bodoroncea, M. Bulancea, V. Constantinescu, D. Grădinaru, C. Jderu, I. Kuglay, C. Meceanu, L. Postelnicu, I. Tocan, AR Trandafir, Code of criminal proceedings. Comment on articles, Ed. C.H. Beck, Bucharest, 2015. 
5. P. Buneci, Gh. Serban, I. Ciolca, I. Dragnea, A. Vasilache, S. Cretu, I. Vasilache, V. Stoica, D. Titian, M. Jiganie-Şerban, New Criminal Procedure Code. Notes. Correlations. Explanations, Ed. C.H.Beck, Bucharest, 2014.

6. P. Bouzat, J. Pinatel. Traite de droit penal et de criminologie. Tome II, LibrairieDalloz, Paris, 1963.

\section{B) Collections, articles, notes:}

1. M. V. Tudoran, The necessity of introducing in the Criminal Procedure Code a new case of revision of final criminal law rulings on Community law. in Law no. 10/2009.

2. H.C.C.J., criminal section, dec.no. 3055 of 12 May 2006; https://legeaz.net/spetepenal-iccj-2006/decizia-3055-2006.

3. S.C., criminal section, dec.nr.853 of 14 February 2002,https://legeaz.net/spete-dreptpenal-csj-2003/decizia-853-2002.

4. H.C.C.J., criminal section, dec.nr.1869 of 17 March 2005; https://legeaz.net/spetepenal-iccj-2005/decizia-1869-2005.

5. S.C., criminal section, dec.nr.2101 of 26 September 1997; https://legeaz.net/spetedrept-penal-csj-1997/decizia-2101-1997.

\section{C) National and European legislation:}

1. http://www.legislationline.org/download/action/download/id/6467/file/Albania_CPC 1995 am2014_en.pdf.

2. http://www.legislationline.org/download/action/download/id/4284/file/Croatia_Crimin al_proc_code_am2009_en.pdf.

3. http://legislationline.org/countries/country/28.

4. http://legislationline.org/documents/section/criminal-codes/country/30.

5. http://www.legislationline.org/download/action/download/id/6449/file/Swiss_CPC_20 07_am2016_en.pdf.

6. Constitutional Court Decision 2/2017, published in the Official Gazette of Romania, Part I, on 5 May 2017.

\section{D) ECHR Jurisprudence:}

1. Case Hronsby v. Greece, Case 18357/91 of 19 March 1997.

2. Mitrea v. Romania, no. 26105/03, July 29, 2008. 